\title{
Global Value Chains, Local Collective Action and Corporate Social Responsibility: a Review of Empirical Evidence
}

\author{
Peter Lund-Thomsen'* and Khalid Nadvi ${ }^{2}$ \\ ${ }^{1}$ Centre for Business and Development Studies, Centre for Corporate Social Responsibility, \\ Copenhagen Business School, Denmark \\ ${ }^{2}$ Institute for Development Policy and Management, School of Environment and Development, \\ University of Manchester, Manchester, UK
}

\begin{abstract}
A key debate in the corporate social responsibility (CSR) literature is the tension between global pressures and local responses. Developing country suppliers often grumble that CSR compliance adds costs. Yet, local collective action, articulated through industry associations, can potentially reduce costs and promote local embeddedness of CSR initiatives. Through case study analysis, this paper considers how demands for CSR compliance prompted collective action responses in selected developing country export industries. We argue that differences in collective responses can be partially explained by how local export industries are inserted into global value chains. We distinguish between 'highly visible' value chains, led by internationally well known brands as lead firms, and relatively 'less visible' chains, where external CSR pressures come from a variety of sources, including less dominant lead firms, international/national regulatory frameworks and national media. This differentiation suggests a possible trade-off between the independence and the embeddedness of collective CSR initiatives. Copyright (C) 2010 John Wiley \& Sons, Ltd and ERP Environment.
\end{abstract}

Received 6 February 2009; revised 7 July 2009; accepted 16 November 2009

Keywords: global value chains; collective action; industrial associations; industrial clusters; corporate social responsibility; developing countries

\section{Introduction}

A

N IMPORTANT TREND IN THE LITERATURE ON CORPORATE SOCIAL RESPONSIBILITY (CSR) AND INTERNATIONAL development is the focus on how small and medium-sized enterprises (SMEs) in the developing world are increasingly confronted with pressures to comply with international labour standards and CSR norms as a pre-condition to access developed world markets. Proponents of CSR codes emphasize that compliance can improve business processes, increase transparency in global supply chain operations and ratchet up social 
and environmental standards in the developing world (Jenkins et al., 2002). Yet, these codes, which are usually based upon internationally agreed labour standards, are also criticized for being formulated in corporate headquarters in Europe or North America without any significant input from the intended beneficiaries, suppliers and workers, in the Global South (De Neve, 2009). Individual global brands insist that their suppliers follow their particular codes of conduct. This often results in local producers facing multiple, costly, and at times contradictory, CSR requirements and audits (Lund-Thomsen, 2008). Consequently, there have been moves towards greater convergence in CSR codes within and across industries (Nadvi, 2008). However, it is unsurprising that many developing country producers feel little ownership for the CSR standards that their Northern buyers press upon them. This raises doubts about the long-term sustainability of social compliance, especially when sustained pressure from international buyers is absent (Barrientos, 2008).

In the context of the debate on global pressures and local responses around CSR codes and international labour, environmental and ethical standards, there have been greater efforts at empirically assessing the gains from compliance, especially on working conditions and workers' lives (see Barrientos and Smith, 2007; Locke et al., 2007; Locke and Romis, 2007). At the same time, calls for a more South-centred CSR agenda that maps out existing CSR practices in developing countries as they are defined by Southern firms, workers and communities are also growing (see Vives, 2006; Singh et al., 2008). A relatively important but under-researched subject is the role that local collective action, often articulated through local industry associations, can play in ensuring meaningful compliance with international labour standards and codes of conduct in the developing world (Nadvi, 2008; LundThomsen and Nadvi, 2009). Local collective action could potentially lower costs of compliance for local producers, improve collective monitoring of codes and more effectively embed the social and environmental goals associated with CSR codes into local practices and norms.

In recent years, the use of multi-stakeholder partnerships (that bring together public and private actors) have been seen as a possible way forward in promoting greater local ownership and participation of local stakeholders in the formulation, implementation and monitoring of CSR standards within global value chains (Dolan and Opondo, 2005; Henkle, 2005; ETI, 2006). This might provide greater scope for coordination and harmonization of codes amongst buyers, thereby reducing the need for individual brands to undertake their own audits. It might also facilitate greater local embeddedness through the involvement of local industry associations in the industry-wide formulation, implementation and monitoring of CSR standards (O’Rourke, 2006; Nadvi, 2008).

Industry and business associations can have an important function in formulating local collective action by SMEs, and thereby promoting local economic development (Doner and Schneider, 2000; Nadvi, I999a). However, the involvement of local industry associations in facilitating compliance with international CSR standards has not been the subject of much debate in the CSR and development-oriented literature. One source of inspiration is the now extant body of empirical studies on developing country industrial clusters. Since the I990s there has been a growing literature on industrial clusters, demonstrating how local industrial competitiveness in the developing world often came from small- and medium-sized firms agglomerated in the same geographical region (Schmitz and Nadvi, I999). In short, the literature highlights the ability of small firms to overcome the barriers they face individually in relation to accessing international markets (Schmitz and Nadvi, I999; Humphrey and Schmitz, 2004). Agglomeration economies and the potential for joint action are the critical elements of collective advantage within clusters. Collective action can improve the capacity of local producers to confront external challenges and enhance competitiveness (Schmitz, I999; Nadvi, I999b; Knorringa, I999; Bair and Gereffi, 200I). Local industrial associations are often at the heart of such collective action (Nadvi, I999a). Yet, even in this literature, few studies explicitly address the question of how external pressures in the form of demands for CSR compliance might trigger collective action responses from industry associations in the developing world. ${ }^{1}$

\footnotetext{
${ }^{\text {I }}$ There are some partial exceptions to this. Nadvi (I999b) details the case of collective action responses by clustered producers to external pressures on compliance with international quality assurance standards, but the study does not provide much detail on CSR standards. Mezzadri (2008) studies CSR in the Delhi Garment cluster. However, she does not explicitly address the question of how external pressures on CSR compliance provoked collective action responses. There are a number of recent policy studies. UNIDO, for example, produced a range of studies that map local CSR practices in clusters in India, Senegal and Ecuador (Accountability (w. UNIDO), 2006; ASK, 2007; Krishnadas et al., 2007; Sodhi, 2007; Sachdeva and Panfil, 2008; Rana and Singh, 2008). Similarly, the ILO describes collective responses to CSR pressures in the cocoa sector (ILO-IPEC, 2007a, 2007b). However, this policy-oriented literature does not contain in-depth analysis of external CSR pressures and local collective action cluster responses.
} 
In this paper, we make an attempt at assessing the limited empirical evidence to date for the potential role that developing country industry associations may play in facilitating collective action responses by export oriented SME producers to CSR pressures originating from the global value chains into which local firms are inserted. In our view, the nature of CSR pressures emanating from the value chain can be varied. We distinguish between what we term 'highly visible' and 'less visible' chains. Highly visible chains are those where scrutiny by the global media and non-governmental organizations (NGOs) has been extensive, often because the chain's lead firms are internationally well recognized global brands. For such firms, brand identity, brand value and brand risks are of paramount concern for both its global marketing and global production organization strategies. Such global brands are often the targets of international and local advocacy groups and the media. Thus, they place great emphasis, and costs, on the ability of local suppliers to comply with their CSR codes in order to mitigate risks to brand integrity. In highly visible chains compliance with social and environmental concerns are central to the organization and governance of the chain and the relationships between local suppliers and global lead firms. In contrast, 'less visible' chains are those where external CSR pressures are driven by a wider set of actors/institutions and/or less dominant global lead firms. On the one hand, less visible chains may include smaller or medium-sized branded buyers less capable of enforcing their CSR demands throughout the chain. On the other hand, external CSR pressures in less visible chains may also reflect a mixture of international/national regulatory frameworks and national media as important CSR drivers in the chain.

In light of this distinction, we analyse seven case studies that are selected using three criteria.

(i) Each of the case studies involves joint industry association CSR responses to external CSR pressures at national, regional or local (cluster) levels.

(ii) They reflect the differential integration of developing country export industries into global value chains. Some of the case studies involve insertion in the 'highly visible' value chains of leading global brands, while others are in comparatively 'less visible' chains.

(iii) The case studies are sufficiently well described in the academic or policy literatures for us to analyse them.

Table I provides an overview of these case studies.

In Table I, we observe that the four case studies of highly visible chains (garments, Bangladesh; cut flowers, Kenya; garments, Cambodia; soccer balls, Pakistan) reflect a largely similar pattern in terms of the initial external pressure and the subsequent collective action response. In all these cases, international media exposure of child labour or labour rights violations in the value chains of internationally branded companies threatened access to global markets. The final three case studies, the Tiruppur dyeing and bleaching sub-cluster, the Palar Valley tannery cluster and the Jalandhar soccer ball cluster, are examples of joint action responses to external pressures in comparatively less visible chains. In these cases, CSR pressures came from a variety of sources including GVCs, international/national regulatory frameworks and national media.

In the next two sections of the paper, we analyse the case studies from both 'highly visible' and 'less visible' chains, to assess how local export industries have formulated through their industry associations similar and different collective action responses to external CSR pressures. We are keen to observe whether the nature of the chain in which local producers are inserted is likely to impact on the types of local collective action response. We show that the differences observed can be partially explained with reference to how local producers are tied into GVCs. Our findings also suggest that there may be a trade-off between maintaining the independence of local collective action CSR initiatives and ensuring their local embeddedness.

\section{External Pressures and Joint CSR Responses: Highly Visible Chains}

The recent literature on standards in global value chains has emphasized the power of lead firms in defining standards and codes of conduct, as well as the ways in which CSR pressures can alter the nature of governance within the value chain (Altenburg, 2006; Dolan and Humphrey, 2004; Gereffi et al., 2005; Hughes, 2005; Humphrey and Schmitz, 2004; Humphrey, 2008; Nadvi, 2008; Ponte and Gibbon, 2005; Ponte, 2007). The interplay between local - national, regional and/or cluster-based - governance and global - value chain based - governance 


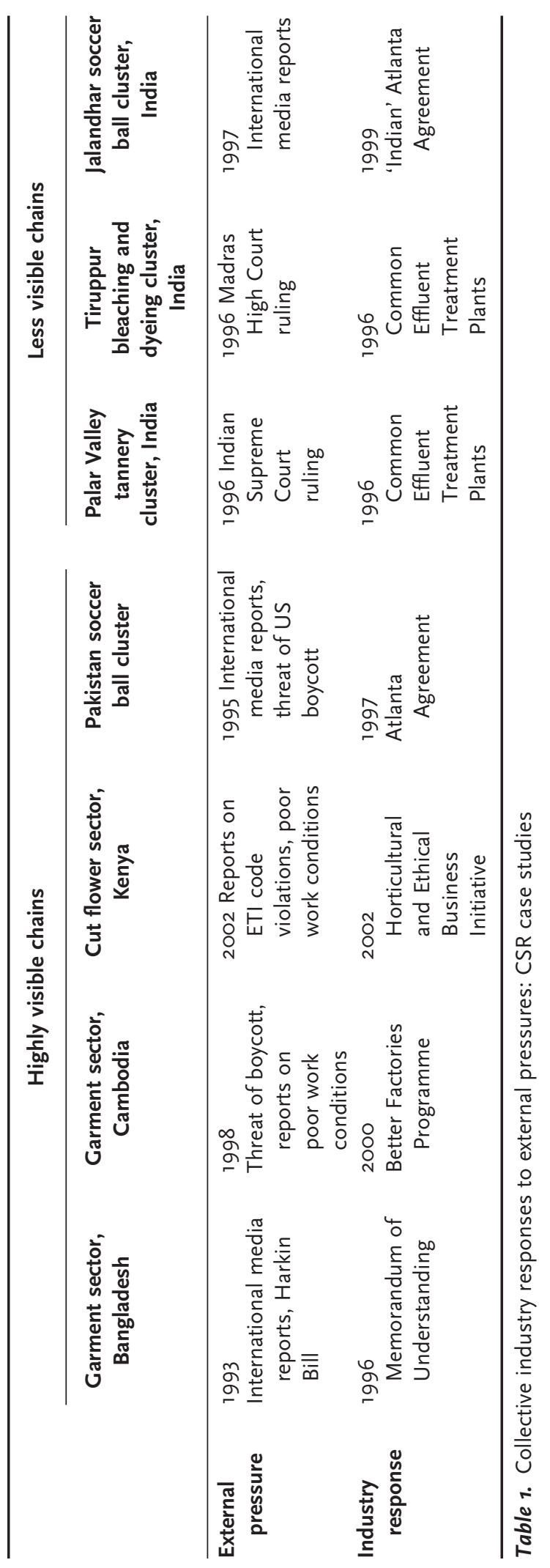


can be critical in determining the ability of local firms to collectively respond to external CSR pressures (Nadvi, 2008).

The first case of a highly visible chain that we review is the Bangladesh garments industry. Leading global apparel brands as well as branded retailers and multiples have been directly sourcing garments from first tier suppliers in Bangladesh since the mid-I980s (Bhattacharya, 2000; Mostafa, 2008). Bangladesh has also been a focus for many advocacy groups concerned with working conditions in labour intensive garment production. In I993, the Harkin Bill passed in the United States Senate called for a ban on imports into the United States (US) of goods manufactured or fabricated by child workers. The Bangladeshi garment industry responded to this by dismissing child workers en masse. Subsequently, a memorandum of understanding was signed between the International Labour Organisation (ILO), the United Nations Children Fund (UNICEF) and the Bangladesh Garment Manufacturers and Exporters Association (BGMEA) aiming to eradicate child labour from the industry by introducing a child labour monitoring system, and providing social protection for affected children (Nielsen, 2005; ILO and UNICEF, 2004).

Our second case study of a highly visible chain is the Kenyan cut flower industry, which supplies leading international retailers, including major branded supermarkets in Europe. Allegations of labour rights abuses on farms prompted members of the UK's Ethical Trading Initiative (ETI) to visit Kenya in 2002. At the same time, local Kenyan stakeholders, fearing the loss of their most important market, organized themselves with the support of the ETI and UK-based NGO Women Workers Worldwide (WWW) to form the Horticultural and Ethical Business Initiative (HEBI) (Dolan and Opondo, 2005). HEBI is an independent non-profit organization, which seeks to improve ethical and social behaviour in the Kenyan horticulture and floriculture industry. In 2002 HEBI set out to investigate the claims of labour rights abuses. It initially undertook a review of other codes. It then developed a base code for its members that reflected Kenyan law, formulated a methodology that could prove malpractices, and trained social auditors in the use of participatory audit methodology of the new code (http://www.hebi.or.ke/, accessed 9 August 2008).

Our third case is the Cambodian garments industry, which supplies major global brand retailers in the United States under the US-Cambodia Free Trade Agreement (USBTA). A stipulation of the USBTA was that local producers met international labour standards as a basis for preferential trade access to the US market. This prompted the Cambodian government and the Cambodian Garment Manufacturers Association (CGMA) to initiate negotiations with the US Department of Labor and the ILO. It is argued that this led to better labour rights monitoring and improved labour standards in the Cambodian garments industry, thereby ensuring market access to the US and enhancing the competitiveness of the Cambodian garment sector (Polaski, 2004, 2006).

Our fourth case is the Pakistani soccer ball industry, clustered in the town of Sialkot. It is the leading global manufacturer of premium quality hand stitched footballs for the major sports goods brands, including Nike and Adidas. In I995 it faced international media allegations of extensive child labour in football stitching activities. A complex negotiation ensued between international brands, UN organizations, NGOs and the local industry, represented through the Sialkot Chamber of Commerce (SCCI). In I997, these parties signed the so-called 'Atlanta Agreement'. The agreement envisaged the development of an industry-wide monitoring mechanism that could identify child workers and transfer them from football stitching to schools while creating social safety nets for their families to make up for the income lost as children were withdrawn from work (Schrage, 2004; Khan, 2007; Rafi Khan, 2004, 2007; Nadvi, 2004, 2008; Seigmann, 2008).

A number of common themes emerge from the four case studies, as shown in Table 2. First, in all four cases the pressures on compliance came from outside the local export industries, usually GVCs that are led by internationally dominating lead firms. These companies are vulnerable to NGO and trade union criticism (regarding child labour or labour rights violations) as this affects their brand value. Second, in all four case studies, the exposure of these brand buyers to media criticism, the brands' demands for CSR compliance and the threat of US regulation (in the Bangladesh, Cambodia and Pakistan cases) prompted a complex multi-stakeholder response involving international and local actors. This was necessary to ensure access to markets in the United States and the EU. Third, central to the responses in all four cases was collective action led by, and organized through, the respective industry associations. Fourth, these responses emerged fairly rapidly in the four case studies. It took from one year to two and a half years from when the initial pressure was experienced until joint action CSR responses were formulated. Fifth, in all of the case studies, funding for local industry responses was provided by international 


\begin{tabular}{|c|c|c|c|c|}
\hline Key buyers & international brands & international brands & international brands & $\begin{array}{l}\text { international brands } \\
\text { (including Nike/ } \\
\text { Adidas) }\end{array}$ \\
\hline Response & 2.5 years & 1 year & 2 years & 2 year \\
\hline $\begin{array}{l}\text { Issues } \\
\text { addressed }\end{array}$ & $\begin{array}{l}\text { child labour } \\
\text { eradication }\end{array}$ & workers' conditions & workers' conditions & $\begin{array}{l}\text { child labour } \\
\text { eradication }\end{array}$ \\
\hline Funding & $\begin{array}{l}\text { US Department of } \\
\text { Labor }\end{array}$ & $\begin{array}{l}\text { DFID, ETI, Royal } \\
\text { Dutch Embassy }\end{array}$ & $\begin{array}{l}\text { US Department of } \\
\text { Labor, Cambodian } \\
\text { Govt, Garment } \\
\text { Manufacturers } \\
\text { Association of } \\
\text { Cambodia }\end{array}$ & $\begin{array}{l}\text { US Department of } \\
\text { Labor, DFID, FIFA, } \\
\text { local industry }\end{array}$ \\
\hline $\begin{array}{l}\text { Implementation } \\
\text { agencies }\end{array}$ & $\begin{array}{l}\text { ILO-IPEC, UNICEF } \\
\text { and BGMEA }\end{array}$ & HEBI & ILO & $\begin{array}{l}\text { ILO-IPEC, UNCEF, } \\
\text { Save the Children- } \\
\text { UK, local NGOs }\end{array}$ \\
\hline $\begin{array}{l}\text { Local industry } \\
\text { association }\end{array}$ & BGMEA & $\begin{array}{l}\text { Kenya Flower } \\
\text { Council }\end{array}$ & $\begin{array}{l}\text { Garment } \\
\text { Manufacturers } \\
\text { Association of } \\
\text { Cambodia }\end{array}$ & $\begin{array}{l}\text { Sialkot Chamber of } \\
\text { Commerce and } \\
\text { Industry }\end{array}$ \\
\hline $\begin{array}{l}\text { Monitoring } \\
\text { mechanism }\end{array}$ & $\begin{array}{l}\text { In-factory } 12 \\
\text { monitoring teams } \\
\text { (2 ILO monitors, } \\
1 \text { govt, } 1 \text { BGMEA) }\end{array}$ & $\begin{array}{l}\text { Social auditing ( } 23 \\
\text { local monitors } \\
\text { educated) }\end{array}$ & $\begin{array}{l}\text { In-factory } \\
\quad(1 \text { international } \\
\text { project director }+ \\
8 \text { local monitors) }\end{array}$ & $\begin{array}{l}\text { In stitching centres } \\
\text { (20 ILO monitors) }\end{array}$ \\
\hline
\end{tabular}

Table 2. Similarities and differences in joint CSR cluster responses to external pressures: highly visible chains

agencies, often by the US Department of Labor in response to the concerns of US labour rights groups (Nielsen, 2005; Dolan and Opondo, 2005; Khan, 2007). Sixth, in three out of the four cases the ILO assumed a leading role in the implementation of collective CSR responses to external pressures, especially through compliance monitoring. ${ }^{2}$ Finally, in all the four case studies market access was assured as a consequence of the compliance initiatives.

Global value chain governance pressures played a significant role in defining the issues to be addressed in all four case studies. The global brand lead firms that organized the respective chains were vulnerable to criticisms relating to labour rights violations and to the presence of child labour. In some cases, most notably the Kenyan cut flower industry and the Cambodian garments industry, NGOs and local trade unions respectively played a part in highlighting labour rights violations. Nevertheless, the key protagonists were external actors. The combination of vertical GVC pressures, in the form of demands for CSR compliance, the threat of boycotts and international media exposure, in the four export industries created a need for the development of relatively sophisticated, horizontal, CSR monitoring mechanisms aimed at ensuring compliance with international labour standards.

This does not imply that local governance and local institutions did not matter in developing collective responses to such external pressures. To the contrary, we argue that local industry associations were important to the formulation and effectiveness of local collective responses. In the case of the Bangladesh garments industry, the BGMEA was a signatory to the Memorandum of Understanding aimed at eradicating child labour from its industry. It was

\footnotetext{
${ }^{2}$ The exception was the Kenyan cut flower industry, where the ILO was not involved with the HEBI. However, as Dolan and Opondo (2005, p. 9I) observed, 'HEBI was a product of direct northern involvement. While ETI, WWW, DFID and the Dutch Embassy only performed a facilitative role in the process, they were nonetheless pivotal to the establishment of a "locally owned" MSP'.
} 
also part of the informal project steering committee with the ILO and UNICEF. ${ }^{3}$ Its assistance made a survey of child labour amongst its approximately 2000 members possible, while the Association had its child labour monitors working alongside ILO and UNICEF throughout the process. ${ }^{4}$

In the Kenyan cut flower industry, international media exposure and the work of international as well as local advocacy groups had already prompted leading local exporters to form the Kenya Flower Council (KFC) in I996. As pressure from local and international activists intensified, the leading local industry associations such as KFC, Fresh Produce Exporters Association of Kenya (FPEAK), the Federation of Kenya Employers and the Agricultural Employers' Association joined with some of their traditional NGO adversaries to form the HEBI. The participation of these industry associations in HEBI was vital to the development of a participatory auditing system, the testing of this auditing system on member farms and the establishment of a baseline for future activities (Dolan and Opondo, 2005).

In the Cambodian garment industry, the CGMA played a significant role in the implementation of the ILO labour monitoring programme. As export licensing is conditional upon membership of the programme, all exportoriented manufacturers in the country as members of the programme must be represented through the CGMA. This implies that all member factories must accept unannounced inspections while they, along with local unions, agree to the use of a checklist of more than 500 items relating to working conditions and labour standards. ${ }^{5}$

In the Pakistan soccer ball industry, the Sialkot Chamber of Commerce and Industry (SCCI) played a key part in negotiating the Atlanta Agreement. It took on the lead role in convincing its members to join the agreement. This involved a commitment amongst its leading members to shift soccer ball stitching from home-based production to especially established stitching centres that could be more easily monitored for child labour. The SCCI members developed an internal child labour monitoring system while committing to continuously providing updated information on the number of stitchers and centres working for them so that the ILO could externally verify this information through its own monitors. The SCCI also financed part of the ILO International Programme on Elimination of Child Labour (ILO-IPEC) monitoring mechanism and undertook to sustain its commitment to the child labour monitoring programme when ILO-IPEC withdrew from this function in 2004 (Lund-Thomsen and Nadvi, 2009).

Hence, while governance pressures emanating from the global value chain were the leading drivers behind the adoption of collective action CSR initiatives in the four cases above, local institutions were instrumental in the effective implementation of collective action responses across all four cases. In each case, local industry associations realized that future exports would be threatened by a failure to engage with the broader CSR demands of international buyers and advocacy groups. These collective bodies were critical in the implementation of CSR monitoring schemes that could ensure compliance and improve their industry's standing in the eyes of stakeholders in Northern-buyer markets.

Although these four case studies share similarities, there are differences in the monitoring mechanisms. First, in the Bangladeshi and Cambodian cases monitoring inspections were factory based. In the Pakistan football cluster, inspections were carried out in designated stitching centres, which had been specially created to better monitor labour. In Kenya, inspections were farm based. Second, timing was another factor in understanding the differences in the design of joint CSR monitoring mechanisms. The introduction of the ILO-IPEC monitoring system in Bangladesh in I996 was an early experiment for the ILO in terms of moving beyond its traditional tripartite role of setting standards to becoming the primary monitoring body for child labour standards. This approach was subsequently used as a model for developing a similar system in the Pakistani soccer ball industry. However, based on the experience from Bangladesh, where many children allegedly wound up in worse occupations, an attempt was made at creating a social protection programme, transferring child workers to schools while creating social safety nets for their families (Husselbee, 2000). Third, the introduction of social auditing by the HEBI in the Kenyan cut flower industry in 2002 marked an attempt at overcoming some of the traditional constraints associated with snap-shot, top-down, compliance-oriented forms of code of conduct monitoring that had since emerged (Dolan and Opondo, 2005). These limitations were, inter alia, associated with tick-box approaches,

\footnotetext{
${ }^{3}$ The Bangladesh Ministry of Labour and the United States Embassy were also represented on this committee.

${ }^{4}$ Source: http://www.childlabor.org/symposium/van_haarlem_lessons.htm, accessed I8 June 2009.

${ }^{5}$ Source: http://www.betterfactories.org/aboutBFC.aspx? $\mathrm{z}=2 \& \mathrm{c}=\mathrm{I} \&$, accessed I 8 June 2009.
} 
little time spent in monitoring at local pack-houses and farms and the use of expensive auditors with limited knowledge of local contexts. Instead, participatory social auditing sought greater involvement of workers, thereby raising their awareness and uncovering less visible issues such as gender discrimination and sexual harassment (Auret and Barrientos, 2004).

In sum, international media exposures, the threat of import bans, international aid organizations and global chain governance pressures were the main drivers behind the establishment of collective CSR responses in the case studies reviewed above. These pressures played an important role in determining the speed of collective cluster responses, the CSR issues to be addressed in these initiatives and the kinds of CSR monitoring mechanism that were developed. While this brought about new forms of monitoring in the four case studies, their effective implementation required local collective action via local industry associations, who often benefited from financial, technical and implementation support from a number of international donor agencies.

\section{External Pressures and Joint CSR Responses: Less Visible Chains}

We now assess the similarities and differences in collective industry responses to external pressures in 'less visible' chains. We start out by outlining the similarities between the three case studies of less visible chains as illustrated in Table 3. First, in the three case studies, the Tiruppur bleaching and dyeing cluster, ${ }^{6}$ the Palar Valley tannery cluster and the Jalandhar soccer ball cluster, external CSR pressures originated from a wider set of actors/institutions including less dominating medium-sized and smaller branded buyers, international/national regulatory frameworks, national media exposure or local NGOs. The Palar Valley tannery cluster was required to comply with two German bans on azo-dyes and PCPs in the mid-I990s (Tewari and Pillai, 2005). It also faced challenges from

$\begin{array}{lc}\text { Palar Valley tannery cluster, } & \text { Tiruppur bleaching and dyeing } \\ \text { India (Kennedy, 1999; Tewari } & \text { cluster, India (Crow and Batz, } \\ \text { \& Pillai, 2005; Kennedy, 2006) } & \text { 2006) }\end{array}$

\& Pillai, 2005; Kennedy, 2006)

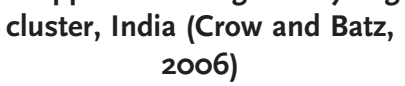

Jalandhar soccer ball cluster, India (LundThomsen and Nadvi, 2009)

\begin{tabular}{|c|c|c|c|}
\hline Key buyers & $\begin{array}{l}\text { National/international } \\
\text { producers of leather } \\
\text { garments, upholstery, and } \\
\text { shoes }\end{array}$ & $\begin{array}{l}\text { National/international } \\
\text { producers of textile garments }\end{array}$ & $\begin{array}{l}\text { Medium-sized/small } \\
\text { sports brands }\end{array}$ \\
\hline Rapidity of response & 1 year & 1 year & 2 years \\
\hline Issues addressed & $\begin{array}{l}\text { Environmental and health } \\
\text { hazards caused by tannery } \\
\text { pollution }\end{array}$ & $\begin{array}{l}\text { Environmental and health } \\
\text { hazards caused by bleachers' } \\
\text { and dyers' pollution }\end{array}$ & Child labour eradication \\
\hline Implementation agencies & $\begin{array}{l}\text { Common effluent treatment } \\
\text { plants }\end{array}$ & $\begin{array}{l}\text { Common effluent treatment } \\
\text { plants }\end{array}$ & SGS, local industry \\
\hline Monitoring mechanism & Present & Present & Present \\
\hline
\end{tabular}

Table 3. Similarities and differences in joint CSR cluster responses to external pressures: less visible chains

\footnotetext{
${ }^{6}$ The Tiruppur bleachers and dyers form a subcluster of the larger Tiruppur knitwear cluster. The main Tiruppur knitwear cluster is estimated to have over I0 000 manufacturing units, employing in excess of 400000 workers with exports of US\$2 billion in 2007 . Eight hundred of these enterprises belong to the bleaching and dyeing subcluster. In terms of demands for compliance with CSR standards, the first-tier knitwear exporters have mostly had to respond to labour concerns from their overseas brand buyers whereas the subcluster have faced local demands for environmental pollution control (Crow and Batz, 2006; de Neve, 2009, p. 64).
} 
local community NGOs, who petitioned the courts to enforce compliance with national environmental laws (Kennedy, I999). Both the Palar Valley tannery cluster and the Tiruppur bleaching and dyeing cluster had to meet Indian Supreme Court orders in I996, prompting both clusters to invest in common effluent treatment plants (CETPs) or face possible firm closures (Kennedy, I999; Crow and Batz, 2006). The Jalandhar soccer ball cluster, whose buyers are mostly medium-sized and smaller sports brands, confronted allegations of child labour in I997. This led to local industrialists forming an industry association, the Sports Goods Foundation of India (SGFI), specifically to eradicate child labour (Lund-Thomsen and Nadvi, 2009; Goyal, 2004, 2005).?

Second, local governance seems to have had a greater role to play in the formation of new industry bodies or associations in the 'less visible' chains. In the Palar Valley and Tiruppur case studies, CETPs, jointly managed by groups of tanneries and bleachers/dyers respectively, were constructed (Tewari and Pillai, 2005; Crow and Batz, 2006). In both cases the local industry took on the collective responsibility for running these plants. In Jalandhar, the sports goods manufacturers association was split between manufacturers of cricket bats and equipment on the one side and soccer ball producers on the other. Given that the focus of CSR pressures was on the soccer ball producers there were divergent views on the need to develop a collective response on child labour. Hence, in I998, soccer ball producers took the lead in setting up SGFI, with the aim of addressing this specific issue and promoting social responsibility initiatives within the cluster.

Third, local industry played a key part in financing these collective action initiatives. For example, in the Palar Valley tannery and Tiruppur bleaching and dyeing clusters, tanners, bleachers and dyers financed the establishment of CETPs with support from federal and state government agencies and Indian development banks (Kennedy, I999; Crow and Batz, 2006). Similarly, in the Jalandhar football cluster, while FIFA gave USD 400 o०o to develop a child monitoring mechanism, a modest social protection programme aimed at transferring children from stitching to school was initially exclusively financed and largely implemented by the SGFI (Lund-Thomsen and Nadvi, 2009).

Fourth, collective action CSR responses to external pressures were formulated relatively quickly in all three cases, from one year in the Palar Valley and Tiruppur clusters to two years for the Jalandhar cluster. A quicker response, however, does not necessarily imply more effective achievement of social or environmental objectives, especially compared with highly visible chains. In fact, as external CSR pressures through the GVC seem to be less critical in the case studies of less visible chains, there was space for 'foot dragging', i.e. attempts by local industry associations to delay or downsize collective action CSR initiatives that they had earlier committed to. For example, the Palar Valley and Tirupur examples had been preceded by years of unsuccessful state- or community-based attempts at bringing local firms into compliance with national environmental legislation. In fact, in both cases, the Tamil Nadu Pollution Control Board promoted the installation of CETPs in I986, but it was only a decade later, after court orders had been issued, that the clusters formulated collective action responses in order to secure their survival (Kennedy, I999; Crow and Batz, 2006). At the same time, while the Palar Valley and Tiruppur clusters reacted quickly after the Supreme Court's ruling, it appeared that implementation of joint action CSR responses in the form of CETPs had slowed considerably. In the Palar Valley only one of eight plants planned or under construction in I997 was functional by 2003 (Kennedy, 2006).

Similarly, the case of the Jalandhar football cluster also illustrates the potential risks of local industry associations taking control of collective CSR monitoring. Initially the Jalandhar child labour monitoring programme, modelled on the Sialkot ILO-IPEC programme, was run by the Swiss accreditation firm SGS, with funding from

\footnotetext{
${ }^{7}$ While the main buyers from Jalandhar are recognized brands, they organized value chains that were 'less visible' than those of the leading sports good brands of Nike and Adidas. The absence of Nike and Adidas from Jalandhar meant that the Jalandhar industry has not faced the same degree of scrutiny as the more well documented case of child labour in Sialkot, Pakistan. It should be noted, however, that recently this may have begun to change. The Jalandhar football industry was in the international spotlight on three occasions in 2008 : first, through the International Labor Rights Forum's report 'Child labor in football stitching activity in India: a case study of Meerut District in Uttar Pradesh' which implicated the Jalandhar cluster in the use of child labour (see http://www.laborrights.org/stop-child-labor/foulball-campaign/I734, accessed 6 May 2009). Second, the Play Fair 2008 Campaign published a report entitled 'Clearing the hurdles - steps to improving the wages and working conditions in the global sportswear industry' in the run-up to the 2008 Olympics in Beijing, claiming that football stitchers' wages in Jalandhar had been stagnant over the past five years (see http://www.playfair2008.org/index.php?Itemid=6I\&id=IO4\&option=com_ content\&task=view, accessed 6 May 2009). Finally, the US-based HBO channel aired a programme entitled 'Real sports with Bryant Gumbel' on I6 September 2008 (see http://soccer.fanhouse.com/2008/09/16/indian-child-labor-exploited-in-production-of-soccer-balls, accessed 6 May 2009) alleging that children were still involved in football stitching in Jalandhar. These allegations have been challenged by the cluster's industry association.
} 
the International Federation of Football Associations (FIFA). However, once FIFA's funding expired in 2003, the local industry association, SGFI, took over monitoring functions with the approval of the World Federation of Sporting Goods Industry. Hence, while labour monitoring was now fully controlled by local industry, its credibility could potentially be challenged due to the reduced level of external and independent scrutiny (Lund-Thomsen and Nadvi, 2009). ${ }^{8}$

An important difference also existed - as in the case studies of highly visible chains - in the design and implementation of CSR monitoring mechanisms. In the case of the Palar Valley tannery and Tiruppur bleaching and dyeing clusters in India, it appeared as if there were relatively well functioning monitoring mechanisms that could measure the treatment efficiency of the CETPs established. ${ }^{9}$ However, the child labour monitoring mechanism in the football industry of Jalandhar seemed potentially weaker than the monitoring mechanism developed in the Pakistani football industry in Sialkot. In Sialkot, a local monitoring body, the Independent Association for the Monitoring of Child Labor, had more monitors at its disposal, carried out more frequent inspections, monitored a larger area and had a more independent board than the SGFI in Jalandhar. In an earlier study, we attributed this difference in the potential strength of the two monitoring mechanisms with the need for the Sialkot producers to retain a stronger mechanism due to the presence of the megabrands Nike and Adidas in the cluster. In fact, the absence of these leading brands in Jalandhar appeared to provide local producers with more leeway to maintain an industry-dominated and relatively less independent monitoring mechanism (Lund-Thomsen and Nadvi, 2009).

In sum, in the absence of sustained pressures from the global value chain, local governance had a larger role to play in the formation, implementation and financing of joint action CSR responses in the case studies of 'less visible' chains. Yet, without sustained external scrutiny, and the threat of exit, by leading global brands, local industry associations in the less visible chains did not face the same pressures to sustain their collective action CSR initiatives. We return to this potential dilemma in the conclusion below.

\section{Conclusion}

In this article we set out to review the evidence on the role that local collective action, articulated through industry associations, might play in the response to CSR pressures by export-oriented SMEs in the developing world. Within the wider debate on global standards and local responses there is very limited understanding of how local collective action is shaped, or how local governance might enhance local embeddedness of external CSR pressures on social and environmental issues. As we stated, academic and policy studies detailing how external pressures in the form of CSR compliance demands have brought about differential collective action responses in the developing world are rather limited. Drawing on a handful of key case studies, we have argued that local collective institutions, in particular industry associations, have an important role to play in framing collective responses to externally generated CSR pressures. In all seven cases reviewed here, the key bodies articulating, implementing and/or in part financing the collective responses were the respective industry associations. While we cannot assess how effective these various responses have been in improving local labour and environmental conditions, they all demonstrate that joint action CSR initiatives remain an important instrument that SMEs use in order to maintain their 'license to operate' and secure continued access to Northern markets.

At the same time, there were substantial differences observed in local collective CSR responses. These differences can partially be explained with reference to the nature of integration into GVCs. We distinguish between highly visible GVCs where external CSR demands originate from globally dominating lead firms on the one hand, and GVCs that are relatively 'less visible' where CSR compliance pressures are driven by a wider set of institutions/actors including less dominant smaller/medium-sized brands, national/international regulation and/or local media/activists. In the case studies of highly visible chains, it appears that international media exposures, the

\footnotetext{
${ }^{8}$ It should be noted however that the SGFI substantially expanded its social protection programme after FIFA's funding stopped in 2003 . This was partly done with the assistance of the United Nations Industrial Development Organization (UNIDO) from 2005 until 2008. As of January 2009 , the SGFI was still sustaining the social protection activities that had been developed in cooperation with UNIDO (Lund-Thomsen and Nadvi, 2009).

${ }_{9}$ Personal communication from Meenu Tewari to the authors, 8 August 2008.
} 
threat of import bans, international aid organizations and global value chain governance pressures determined the rapidity of the local joint action responses to CSR pressures, the issues to be addressed in these initiatives and even the types of collective action that emerged in response to such pressures. This is not to say that local institutions and local governance did not matter. In all of the cases of highly visible chains reviewed here, there were significant local actors, representing collective voices within their respective case studies, that were central in the implementation of collective action responses.

In our view there may be greater scope for the development of local industry-wide CSR responses in less visible chains where external CSR pressures are driven by less dominating medium-sized and smaller brands, international/national regulatory frameworks and/or national media. In such instances, local industry institutions are more likely to emerge as the key driver, or protagonist, in articulating a local collective response to CSR pressure. However, this seems to come at a price. Local industry associations might be prone to delay or downscale the nature of their joint action responses in the absence of tough, sustained pressure from internationally branded buyers or advocacy organizations. Furthermore, additional research is needed to probe how collective action is brought about within industry associations, and to explore how diverse interests are negotiated and managed within such local institutions.

Our analysis suggests that policy makers have to navigate between the competing demands of maintaining the independence and local embeddedness of joint action CSR initiatives in developing country export industries. On the one hand, the threat of boycotts, the compliance demands of brand buyers and intense scrutiny from international media and advocacy NGOs may be required for developing and maintaining relatively independent joint action CSR initiatives aimed at identifying and preventing child labour and labour rights violations. However, these joint action CSR initiatives are unlikely to become more locally embedded unless there is scope for local governance structures in their formation, implementation and financing. We suggest that this potential trade-off between the independence and local embeddedness of joint action CSR initiatives may be fruitful to consider in the light of the future development of similar initiatives in other localities in the developing world.

\section{Acknowledgements}

This article draws on an earlier study, 'Global value chains, industrial clusters, and CSR: a comparative assessment of the sports goods clusters in Sialkot, Pakistan and Jalandhar, India' (Lund-Thomsen and Nadvi, 2009) commissioned by the United Nations Industrial Development Organisation (UNIDO), Vienna. The views represented here are solely those of the authors and do not reflect in any way on the position of UNIDO. The authors thank two external reviewers and Anne Tallontire for helpful and insightful comments on previous drafts. The usual caveats apply.

\section{References}

Accountability (w. United Nations Industrial Development Organisation (UNIDO)). 2006. SME Clusters and Responsible Competitiveness in Developing Countries. Accountability: London.

Altenburg T. 2006. Governance patterns in value chains and their developmental impact. European Journal of Development Research I8(4): $498-521$.

Association of Stimulating Know-How (ASK). 2007. Report of Mapping of Enterprise Social Responsibility (ESR) Practices of Brass Metalware Industry - Moradabad. United Nations Industrial Development Organisation (UNIDO): New Delhi.

Auret D, Barrientos S. 2004. Participatory Social Auditing: a Practical Guide to Developing a Gender Sensitive Approach, IDS Working Paper 237. Institute of Development Studies, University of Sussex: Brighton.

Bair J, Gereffi G. 200I. Local clusters in global chains: the causes and consequences of export dynamism in Torreon's blue jeans industry. World Development 29(II): I885-I903.

Barrientos S. 2008. Contract labour: the 'Achilles heel' of corporate codes in commercial value chains. Development and Change 39(6): 977990.

Barrientos S, Smith S. 2007. Do workers benefit from ethical trade? Assessing codes of labour practice in global production systems. Third World Quarterly 28(4): 713-729.

Bhattacharya D. 2000. Emergence and growth of the RMG sector in Bangladesh. In Strategies for Industrialisation: The case of Bangladesh, Huq M, Love J (eds). University Press: Dhaka; 303-32I.

Crow M, Batz MB. 2006. Clean and competitive? Small-scale bleachers and dyers in Tirupur, India. In Small Firms and the Environment in Developing Countries: Collective Impacts, Collective Action, Blackman A (ed.). REF Press: Washington, DC. 
De Neve G. 2009. Power, inequality and corporate social responsibility: the politics of compliance in the South Indian garment industry. Economic and Political Weekly 44(22): 63-7I.

Dolan CS, Humphrey J. 2004. Changing governance patterns in the trade in fresh vegetables between Africa and the United Kingdom. Environment and Planning A 36(3): 49I-509.

Dolan CS, Opondo M. 2005. Seeking common ground - multi-stakeholder processes in Kenya's cut flower industry. Journal of Corporate Citizenship 18: 87-98.

Doner RF, Schnieder BR. 2000. Business associations and economic development: why some associations contribute more than others. Business and Politics 2(3): $26 \mathrm{I}-288$.

Ethical Trading Initiative (ETI). 2006. ETI Code of Labor Practice - Do Workers Really Benefit? Institute of Development Studies: Brighton.

Gereffi G, Humphrey J, Sturgeon T. 2005. The governance of global value chains. Review of International Political Economy I2(I): 78-I04.

Goyal P. 2004. Child labour in the sports goods industry: findings from a survey in selected bastis of Jalandhar. Social Change 34(I): 66-74.

Goyal P. 2005. Little Hands That Work - Child Labour in Punjab. PBG Publications: Ludhiana.

Henkle D. 2005. Gap Inc. sees supplier ownership of compliance with workplace standards as an essential element of socially responsible sourcing. Journal of Organizational Excellence 25(1): 17-25.

Hughes A. 2005. Corporate strategy and the management of ethical trade: the case of the UK food and clothing retailers. Environment and Planning A 37: II45-II63.

Humphrey J. 2008. Private Standards, Small Farmers and Donor Policy: EUREPGAP in Kenya, Institute of Development Studies (IDS) Working Paper 308. IDS: Brighton.

Humphrey J, Schmitz H. 2004. Governance in global value chains. In Local Enterprises in the Global Economy: Issues of Governance and Upgrading, Schmitz H (ed.). Elgar: Cheltenham; 95-Io9.

Husselbee D. 2000. NGOs as development partners to the corporates: child football stitchers in Pakistan. Development in Practice Io(3/4): $377-389$.

International Labour Organisation (ILO), UNICEF. 2004. Addressing Child Labour in the Bangladesh Garment Industry 1995-2001 - a Synthesis of UNICEF and ILO Evaluation Studies of Bangladesh Garment Sector Projects. ILO: Geneva.

ILO International Programme on Elimination of Child Labour (ILO-IPEC). 2007a. Rooting Out Child Labour from Cocoa Farms - Paper No. 3: Sharing Experiences. ILO: Geneva.

ILO International Programme on Elimination of Child Labour (ILO-IPEC). 2007b. Rooting Out Child Labour from Cocoa Farms - Paper No. 4: Child Labour Monitoring - a Partnership of Communities and Government. ILO: Geneva.

Jenkins R, Pearson R, Seyfang G. 2002. Introduction. In Corporate Responsibility and Labour Rights - Codes of Conduct in the Global Economy, Jenkins R, Pearson R, Seyfang G (eds.). Earthscan: London; I-I2.

Kennedy L. I999. Co-operating for survival: tannery pollution and joint action in the Palar Valley. World Development 27(9): I673-169I.

Kennedy L. 2006. Improving environmental performance of small firms through joint action: Indian tannery clusters. In Small Firms and the Environment in Developing Countries - Collective Action and Collective Impacts, Blackman A (ed.). RFF Press: Washington, DC.

Khan A. 2007. Power, Policy and the Discourse on Child Labour in the Football Manufacturing Industry of Sialkot. Oxford University Press: Karachi.

Knorringa P. 1999. Agra: an old cluster facing the new competition. World Development 27(9): 1587-1604.

Krishnadas K et al. 2007. Mapping of Social Enterprise Responsibility (ESR) Practices in Kalady Rice Mill Cluster. United Nations Industrial Development Organisation (UNIDO): New Delhi.

Locke RM, Romis M. 2007. Improving work conditions in global supply chain. MIT Sloan Management Review 48(2): 54-62.

Locke RM, Qin F, Brause A. 2007. Does monitoring improve labor standards? Lessons from Nike. Industrial and Labor Relations Review 6I(I): 3-3I.

Lund-Thomsen P. 2008. The global sourcing and codes of conduct debate: five myths and five recommendations. Development and Change 39(6): 1005-IOI8.

Lund-Thomsen P, Nadvi K. 2009. Global Value Chains, Local Clusters, and Corporate Social Responsibility: a Comparative Assessment of the Sports Goods Clusters in Sialkot, Pakistan and Jalandhar, India, Technical Paper I7. Industrial Policy and Private Sector Development Branch, United Nations Industrial Development Organisation (UNIDO): Vienna.

Mezzadri A. 2008. Assessing the Effectiveness of Corporate Social Responsibility as a Tool for 'Poverty Reduction through Protective Activities': The Case of Delhi Garment Cluster, United Nations Industrial Development Organisation (UNIDO) Working Paper, Vienna.

Mostafa H. 2008. Recognizing complexity, embracing diversity: working children in Bangladesh. South Asia Research 28(I): 49-72.

Nadvi K. I999a. Facing the New Competition: Business Associations in Developing Country Industrial Clusters, Working Paper I03. International Institute for Labour Studies (ILO): Geneva.

Nadvi K. I999b. Collective efficiency and collective failure. World Development 27(9): 1605-1626.

Nadvi K. 2004. The effect of global standards on local producers: a Pakistani case study. In Local Enterprises in the Global Economy: Issues of Governance and Upgrading, Schmitz H (ed.). Elgar: Cheltenham; 297-325.

Nadvi K. 2008. Global standards, global governance and the organisation of global value chains. Journal of Economic Geography 8(3): 323343.

Nielsen ME. 2005. The politics of corporate responsibility and child labour in the Bangladeshi garment industry. International Affairs 8I(3): $559-580$.

O'Rourke D. 2006. Multi-stakeholder regulation: privatizing or socializing global labor standards? World Development 34(5): 899-918.

Polaski S. 2004. Cambodia Blazes a New Path to Economic Growth and Job Creation, Carnegie Paper 5I. Carnegie Endowment for International Peace: Washington, DC. 
Polaski S. 2006. Combining global and local forces: the case of labour rights in Cambodia. World Development 34(5): 919-932.

Ponte S. 2007. Governance in the Value Chain for South African Wine. TRALAC Working Paper no. 9, Trade and Law Centre for Southern Africa. University of Stellenbosch: Stellenbosch.

Ponte S, Gibbon P. 2005. Quality standards, conventions, and the governance of global value chains. Economy and Society 34(I): I-3I.

Rafi Khan F. 2004. Hard times recalled - child labor in Pakistan's soccer ball industry. In International Business and the Dilemmas of Development, Bird F (ed.). Palgrave-MacMillan: Basingstoke; I32-I55.

Rafi Khan F. 2007. Representational approaches matter. Journal of Business Ethics 73(I): 77-89.

Rana S, Singh N. 2008. Enterprise Social Responsibility in MSMEs Cluster - Jalandhar Sports Goods MSMEs Cluster (Punjab) - Survey Report (India) 2007-8. United Nations Industrial Development Organisation (UNIDO): New Delhi.

Ruwanpura KN, Roncolato L. 2006. Child rights: an enabling or disabling right? The nexus between child labour and poverty in Bangladesh. Journal of Developing Societies 22(4): 359-378.

Sachdeva A, Panfil O. 2008. CSR Perceptions and Activities of Small and Medium Enterprises (SMEs) in Seven Geographical Clusters - Survey Report. United Nations Industrial Development Organisation (UNIDO): Vienna.

Schmitz H. I999. Global competition and local cooperation: success and failure in the Sinos Valley, Brazil. World Development 27(9): I627I650.

Schmitz H, Nadvi K. I999. Clustering and industrialisation: special issue - Introduction. World Development 27(9): I503-I5I4.

Schrage EJ. 2004. Promoting International Worker Rights Through Private Voluntary Initiatives: Public Relations or Public Policy? Centre for Human Rights, University of Iowa: Iowa City.

Seigmann KA. 2008. Soccer ball production for Nike. Economic and Political Weekly 3I May: 57-64.

Singh N et al. 2008. Consolidated Report of Enterprise Social Responsibility Mapping of 7 Industrial Clusters. United Nations Industrial Development Organisation (UNIDO): New Delhi.

Sodhi JS. 2007. Report on Enterprise Social Responsibility and SME Cluster Development of Ludhiana Garment Industry Cluster. United Nations Industrial Development Organisation (UNIDO): New Delhi.

Tewari M, Pillai P. 2005. Global standards and the dynamics of compliance in the Indian leather industry. Oxford Development Studies 33(2): $245-267$.

Vives A. 2006. Social and environmental responsibility in small and medium enterprises in Latin America. Journal of Corporate Citizenship 2I: 39-50. 